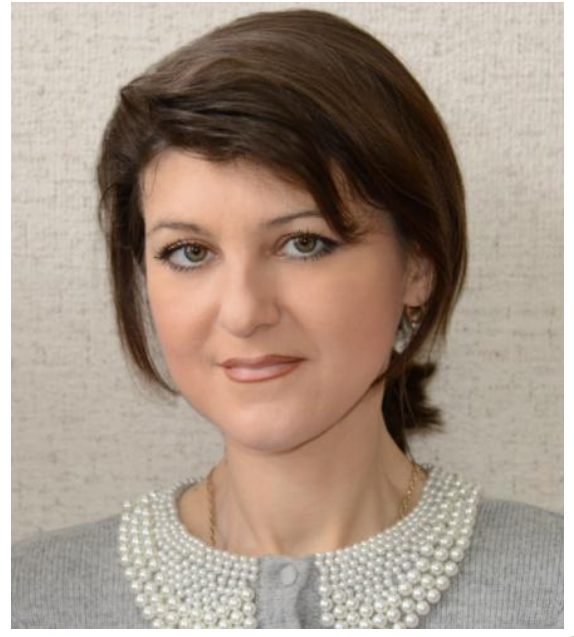

ПЛАНУВАННЯ РОЗСЛІДУВАННЯ КРАДІЖОК, УЧИНЕНИХ ГРУПАМИ НЕПОВНОЛІТНІХ

\author{
I. О. МАНЖОС, \\ здобувач кафедри криміналістики, \\ Національний юридичний університет \\ імені Ярослава Мудрого, \\ Україна, м. Харків \\ e-mail: 1irisha10@mail.ru
}

Розглянуто планування у кримінальних провадженнях щодо учинення крадіжок групами неповнолітніх як найважливішу частину досудового розслідування, від якої залежить його якість та ефективність. Розроблено відповідні рекомендації й визначено послідовність слідчих (розиукових) дій та версії, щз мають бути включені до структури плану.

Ключові слова: крадіжка, планування розслідування злочинів, група неповнолітніх, криміналістична версія.

Постановка проблеми. На нинішньому етапі розвитку українського суспільства дуже загострилася проблема якості досудового розслідування, яка тісно пов'язана 3 плануванням розслідування. Ця проблема повною мірою відноситься і до розслідування злочинів, учинених групами неповнолітніх.

Актуальність теми. Розслідування крадіжок, учинених групами неповнолітніх, є специфічним за своєю суттю, що зумовлено специфікою даної форми злочинності, особливостями кримінального провадження та доказування щодо злочинів неповнолітніх, а також тим, що в досудовому розслідуванні мають бути повною мірою забезпечені їх права і законні інтереси, що пояснює особливу процедуру планування розслідування та окремих слідчих (розшукових) дій.

Аналіз останніх досліджень і публікацій. Проблеми планування та висування версій у кримінальному провадженні аналізували у своїх працях А. Л. Дудніков [1], В. А. Журавель [2], О. Н. Колесниченко [4], В. О. Коновалова [7], Г. А. Матусовський [4], М. С. Остапчук [8], В. М. Шевчук (C) Манжсо I. O., 2015 
[12], В. Ю. Шепітько [5-6] та інші науковці.

У криміналістичній літературі здійснювалися спроби узагальнити різні підходи до проблем, які стосуються визначення сутності планування розслідування. Результатом досліджень вітчизняних криміналістів стала цілком обгрунтована думка, що під плануванням розслідування слід розуміти визначення шляхів розкриття злочинів, окреслення обставин, які підлягають 3'ясуванню, а також встановлення строків проведення необхідних слідчих дій, оперативно-розшукових заходів та ін. [6, с. 321]. Безпосередньо планування спрямоване на ефективне й швидке розкриття і розслідування злочинів. За своєю суттю - це визначення оптимальних шляхів, етапів і слідчих дій, спрямованих на розслідування кримінального правопорушення [12, с. 102].

Дослідники справедливо зазначають, що організованість і плановість розслідування кримінальних правопорушень виступають передумовою виконання завдання розслідування, дотримання його строків, якісного проведення окремих процесуальних дій та застосування заходів із забезпечення кримінального провадження [9, с. 345].

У той же час, розглядаючи загальні підстави планування досудового розслідування, слід зупинитися на окремих, специфічних провадженнях, а саме - звернути увагу на планування у кримінальних провадженнях щодо учинення крадіжок групою неповнолітніх.

Метою статті є дослідження проблем щодо планування розслідування крадіжок, що учиняються групами неповнолітніх.

Виклад основного матеріалу. Планування розслідування злочину $\epsilon$ важливішим елементом організаційної діяльності слідчого. Така діяльність має плановий характер, оскільки від правильно спланованого розслідування залежать його ефективність та подальша результативність [3]. Сутність планування розслідування у кримінальних провадженнях полягає в тому, що воно грунтується на всебічному врахуванні фактичних даних, $€$ за своєю сутністю динамічним процесом, коли складений план доповнюється, змінюється, корегується і планування, а отже, є безперервним, таким, яке () Манжсос I. O., 2015 
триває протягом усього досудового розслідування [8, с. 221].

Що стосується розслідування крадіжок, учинених групами неповнолітніх, то ці злочини характеризуються великим обсягом і трудомісткістю слідчих (розшукових) дій у зв’язку з груповим характером цих злочинів, значною кількістю версій, розширенням кола обставин, що підлягають встановленню (статті 485, 487 КПК), залученням додаткових учасників до процесуальних дій (статті 488, 491, 496 КПК) [7].

Під час планування розслідування злочинів неповнолітніх враховується, що такі провадження характеризуються трудомісткістю слідчих (розшукових) дій, що пов’язано з груповим, як правило, характером більшості злочинів, більш широким колом обов'язкових версій та необхідністю реалізації додаткових процесуальних гарантій.

Якщо розглядати планування слідчих (розшукових) дій як певний послідовний процес, то таке планування за своїм змістом має відповідати властивостям процесу розслідування.

Планування на початку розслідування у більшості випадків зазвичай характеризується інформаційною невизначеністю, i саме недостатність первинних даних найчастіше змушує слідчого планувати розслідування за схемою «типові слідчі ситуації - типові слідчі версії - програма розслідування - системи слідчих (розшукових) дій (тактичні операції) [2, с. 27].

Вдаючись до даної схеми, вже на початку розслідування крадіжок, учинених групою неповнолітніх, на нашу думку, слідчий повинен передбачати:

1) версії про груповий характер крадіжки і про учинення даного злочину неповнолітніми. В обставинах, що підлягають з'ясуванню, слід конкретизувати роль кожного з членів злочинної групи (чи не були вони втягнуті у злочин дорослими), з урахуванням інформації, наявної на момент складання плану, отриманої в ході слідчих і оперативно-розшукових заходів;

2) версії про кількісний і якісний склад злочинної групи, яка вчинила крадіжку, спосіб їі учинення, дії з приготування і приховування слідів, роль і місце кожного члена групи у загальній структурі злочину; 
3) версії про наявність дорослого організатора злочину, яка грунтується на аналізі способу учинення злочину, показаннях свідків, огляду місця злочину, слідів злочину та ін.;

4) версії про те, що злочин було учинено знайомим потерпілого, який мав доступ до приміщення, до ключів від приміщення;

5) версії про те, що крадіжку інсценовано потерпілим 3 метою приховування крадіжки, пошкодження майна, що учинені самим потерпілим.

Підкреслюючи значущість запропонованого підходу, О. Н. Колесніченко та Г. А. Матусовський вказували на те, що використання систем типових версій надає розслідуванню елементів точності, повноти, дає змогу слідчому проаналізувати відомі йому аналогічні ситуації та відібрати аналогічні 3 конкретним випадком з інших джерел. Ознайомлення зі схемою таких версій дозволяє одночасно охопити й перспективно намітити всі можливі основні напрями розслідування [4, с. 10$]$.

Сам процес висування версій грунтується на ретельному вивченні i аналізі матеріалів кримінального провадження, на всебічному аналізі способу вчинення злочину, на досліджені характерних слідів й ознак, які мають важливе значення для забезпечення слідства інформацією не тільки про спосіб, а й про інші елементи криміналістичної характеристики, в тому числі й про особу злочинця [1].

За кожною версією необхідно з'ясувати низку обставин, які підлягають встановленню. Оскільки всі версії перевіряються паралельно, то потрібно визначити обставини загального характеру і намітити слідчі та оперативнорозшукові заходи для їх перевірки.

На початку розслідування у плані доцільно визначити коло таких слідчих (розшукових) дій, невідкладних за своєю суттю, які здатні розширити доказову базу для переходу до наступного етапу планування і розслідування. Це огляд місць подій, допити очевидців та інших свідків, обшуки у підозрюваних осіб та ін. На перший план виступає визначення завдань цих слідчих (розшукових) дій, організація і черговість їх проведення, склад учасників та інші питання, що () Манжос I. O., 2015 
підлягають встановленню.

Наприклад, при плануванні огляду місця події доцільно додати до плану низку таких питань:

1) про об’єкт, в якому проводиться обшук: а) точна адреса об’єкта, що підлягає обшуку; б) конкретне призначення будівлі та окремих іiі частин; в) умови експлуатації, кількість і склад осіб, які постійно проживають або працюють у даному приміщенні; г) спосіб або можливі шляхи проникнення у приміщення і виходи з нього, наявність сигналізації, охорони, засобів зв'язку; д) внутрішнє планування, розташування приміщень; е) наявність обстановки, меблів, механізмів та інших предметів, їх розміщення, властивості та особливості;

2) про осіб, які займають дане приміщення: а) професія і рід занять; б) схильність i характер проведення дозвілля; в) спосіб життя, звичайний розпорядок у родині, г) поведінку у побуті, на робочому місті, на місці навчання; д) зв'язки і знайомства;

3) викрадені предмети: а) розмір, вага, форма, кількість предметів; б) матеріали, з яких вони виготовлені; в) щільність, консистенція та інші властивості; г) зовнішній вигляд, яскраві риси і відмінні ознаки; д) можливість зміни цих ознак і властивостей; е) призначення та цінність даних предметів.

Під час огляду місця подіiі, слідчий має комплексно розглядати та аналізувати спосіб, обстановку та виявлені сліди для висування версій про місця знаходження ще не виявлених слідів, про особу неповнолітнього злочинця [11], а також про можливий груповий характер злочину, про те, чи був він учинений неповнолітніми.

Якщо отримано достовірну інформацію про те, що злочин учинений неповнолітніми, робота 3 його розкриття повинна здійснюватися в напрямах, що мають бути відповідним чином заплановані:

1. Виявлення на території, що обслуговується, груп неповнолітніх i встановлення мотивів їх об'єднання та спрямованість дій. Практика показує, що значне число крадіжок неповнолітні вчиняють у районі свого проживання або в (C) Манжес I. O., 2015 
безпосередній близькості від нього. Цінні відомості про групи неповнолітніх можна отримати від дільничних уповноважених і працівників інспекцій у справах неповнолітніх. Саме у поле зору цих осіб потрапляють неповнолітні, які організовуються в групи, i ïх завдання полягає в тому, щоб знати справжні мотиви такого об’єднання, вміти правильно і своєчасно впливати на наміри і дії неповнолітніх.

2. Встановлення неповнолітніх, в яких після учинення злочину з'явилися гроші, нові предмети, речі. Для цього на облік беруть викрадене майно і про його ознаки доводять до відома працівників органів внутрішніх справ. Особливу увагу звертають на місця можливого збуту викраденого, які в кожному конкретному випадку залежать від характеристики обслуговуваної ділянки.

3. Встановлення осіб, яким відомі обставини учиненого злочину. Для цього, виходячи 3 аналізу місця, часу, обставин учинення злочину, можна визначити мешканців квартир, з вікон яких видно місце злочину і підходи до нього; особи, які в цей час проходили неподалік від місця злочину, йдучи на роботу, навчання, додому та ін.; працівники міського транспорту, яким могли скористатися неповнолітні, що звернули на себе увагу через незвичайну поведінку.

Після виконання запланованих слідчих дій i оперативно-розшукових заходів, спрямованих на уточнення обставин учиненого злочину, розшук викраденого майна і обізнаних осіб, встановлення особи, яка його вчинила, обсяг інформації про учинений злочин розширюється. Це дозволяє конкретизувати висунуті раніше версії про обставини злочину і осіб, які вчинили його та уточнити напрями розслідування.

Напрям розслідування, характер і послідовність слідчих дій і оперативнорозшукових заходів залежать від ступеня визначеності зібраної до цього часу інформації [10], мають плануватися з оглядом на наступні принципи:

1) системність взаємопов язаних слідчих (розшукових), негласних слідчих (розшукових) дій, оперативно-розшукових, організаційно-технічних та () Манжсос I. O., 2015 
інших дій (заходів) алгоритмічного характеру; 2) обумовленість цієї системи дій слідчою та судовою ситуацією на певному етапі кримінального провадження; 3) спланованість тактичної операції, тобто дії та заходи такої операції провадяться за єдиним планом; 4) керівна (управлінська) роль слідчого, прокурора (за винятком оперативно-тактичних операцій, де керівником може бути і посадова особа оперативних підрозділів), а в судовому проваджені - судді; 5) спрямованість дій та заходів на вирішення окремого тактичного завдання у досудовому розслідуванні та судовому провадженні.

Також під час планування доцільно визначити ті засоби, які мають бути застосовані для ефективної та повноцінної реалізації тієї чи іншої слідчої дії. 3 урахуванням характеру і умов слідчої дії план може передбачати використання: a) переносних засобів освітлення (акумуляторні або батарейні ліхтарі, лампи, свічки тощо); б) оптичних приладів (лупа, мікроскоп, бінокль та ін.); в) вимірювальних засобів (рулетка, лінійка, штангенциркуль); г) інструментів для відкриття сховищ (молоток, пила, викрутка, ніж); д) пакувальних матеріалів (обгортковий папір, поліетиленові пакети, пробірки, клейонка, шпагат, сургучна печатка тощо); е) пошукових засобів (щупи, багри, джерела інфрачервоного і ультракороткого випромінювання та ін.); ж) засобів орієнтації (карта місцевості, план споруди, компас, рівень, ватерпас та ін.); з) засобів закріплення доказів (бланки елідчих дій, міліметровий папір, авторучка, портативний компютер, олівці, гіпс, паста для копіювання рельєфних слідів, порошки для виявлення невидимих слідів, магнітна кисть, фото- і відеокамера, магнітофон).

Застосування даного інструментарію має бути визначено заздалегідь, перелік конкретних інструментів та засобів має бути включено до плану із вказівкою тієї особи, що має забезпечити їх доставку до місця виконання тієї чи іншої слідчої ( розшукової) дії.

Планування $є$ динамічним процесом, супроводжується постійним коректуванням плану, що пов'язано 3 надходженням нової інформації, висуванням нових або зміною попередніх версій, різними непередбаченими () Манжос I. O., 2015 
обставинами (неможливість за тими чи іншими причинами проводити заплановані дії, неякісне проведення експертизи та ін.).

При цьому слід звернути увагу на те, що дії слідчого спрямовані не лише на збирання доказів, але і на їх ретельну оцінку і систематизацію. Одержувана інформація дозволяє оцінити висунуті версії, замінити їх новими або внести до них необхідні корективи, відповідно до цих змін планується проведення всіх необхідних експертиз, додаткових допитів, оглядів, іноді повторних обшуків.

Зазначимо, що на процес планування істотно впливає позиція підозрюваних, обвинувачених, їх захисників. При запереченні вини і наданні неправдивих свідчень у плані розслідування передбачаються дії 3 перевірки заявленого алібі, проведення очних ставок, повторних детальних допитів, дії, спрямовані на задоволення клопотань зазначених осіб.

При складанні плану розслідування конкретного злочину слідчий повинен виділити в окрему графу виконавців і строки виконання слідчих, оперативно-розшукових та інших заходів, оскільки при розслідуванні вищезазначеної категорії злочинів слідчий взаємодіє 3 різними органами i повинен мати чітке уявлення, хто і в які строки має виконати те чи інше доручення.

Підготовка слідчих (розшукових) дій при розслідуванні групових крадіжок, учинених неповнолітніми, складна і вимагає чималого часу, оскільки у деяких 3 них, наприклад, у допиті неповнолітнього підозрюваного чи обвинуваченого беруть участь не тільки слідчий, але і оперативні працівники, законний представник, педагог, психолог або лікар (ст. 491 КПК України). Відповідно при плануванні необхідно передбачити дії, що спрямовані на повноцінне забезпечення прав цих осіб та виконання ними відповідних обов'язків.

При плануванні слідчих (розшукових) дій за участю неповнолітніх особливу увагу слід звертати на час їх проведення, а також, із урахуванням швидкої стомлюваності неповнолітніх, не слід планувати проведення декількох слідчих (розшукових) дій поспіль за участю одного і того ж неповнолітнього [6, (C) Манжос I. O., 2015 
c. 331-332].

Оскільки вищевказані злочини мають груповий характер, недоцільно запрошувати відразу після проведення слідчої (розшукової) дії за участю одного із спільників злочинної групи іншого учасника, оскільки несвоєчасне закінчення слідчої дії (наприклад, вчасно не прибув адвокат, законний представник або психолог і т. ін.), або передчасне прибуття інших учасників може призвести не тільки до поспіху і неуважності слідчого, але і до зустрічі співучасників крадіжки, обміну інформацією між ними, i, в результаті, до зміни показань одного 3 неповнолітніх, що негативно позначиться на ефективності слідчої дії та усього розслідування.

У цілому, щоб уникнути таких ускладнень, слідчий повинен передбачити у своєму плані перерви між слідчими діями за участю неповнолітніх співучасників крадіжки, а в цей час зайнятися складанням інших процесуальних документів, що вимагають участі неповнолітніх.

Окрім того, план передбачає так само i дії слідчого 3 розшуку підозрюваного або обвинуваченого, які ховаються (винесення відповідних постанов, оголошення у розшук та ін.).

Слідчим плануються дії щодо ознайомлення підозрюваного та його захисника з матеріалами закінченого досудового розслідування; дії, пов'язані із задоволенням заявлених підозрюваним і його захисником клопотань; дії, визначені прокурором або керівником слідчого підрозділу; додаткові дії, проведені з ініціативи самого слідчого в результаті оцінки зібраних доказів перед складанням обвинувального акта [5].

Планується робота зі складання обвинувального акта, підготовки всіх додатків до нього, приведення матеріалів справи у належний вигляд перед направленням іiі до суду.

Отже, процес досудового розслідування потребує специфічних підходів до планування, динамічність надходження інформації щодо крадіжки, яка учинена групою неповнолітніх, вимагає застосування специфічних слідчих (розшукових) дій і розуміння слідчим загального процесуального порядку та () Манжсос I. O., 2015 
методичних підходів до розслідування цих злочинів, поєднаних із якісним плануванням, створюють підстави для загального успіху досудового розслідування.

Висновки. Таким чином, при розслідуванні крадіжок, учинених групою неповнолітніх, правильна організація планування, своєчасне висунення версій дозволяють швидко реагувати на учинений злочин і більш раціонально використовувати сили і засоби, спрямовані на розслідування i розкриття злочину. Всі висунуті версії перевіряються шляхом проведення комплексу слідчих і оперативно-розшукових заходів, запланованих для відпрацювання. Намагання окремих працівників правоохоронних органів вести розслідування цих злочинів без плану тягне за собою ускладнення у слідчій роботі, заважає реалізації системного підходу при розслідуванні крадіжок, учинених групою неповнолітніх.

Водночас слід мати на увазі, що найдосконаліший, глибокий, такий, що відкриває Перспективу, план розслідування піддається постійному коригуванню. 3 цього не випливає, що при складанні початкового плану розслідування можна знехтувати вимогами всебічності i глибини аналізу матеріалів, що надійшли, детальною розробкою версій, навпаки - саме детальне опрацювання попереднього плану розслідування сприяє можливостям його безболісної корекції 3 урахуванням ситуації, яка складається під час розслідування кримінального правопорушення.

\section{Список літератури:}

1. Дудніков А. Л. Криміналістичне поняття «спосіб злочину» [Електронний ресурс] / А. Л. Дудніков. - Режим доступу : http://cyberleninka.ru/article/n/kriminalisticheskoe-ponyatiesposob-prestupleniya.

2. Журавель $\quad B . \quad A$. Профілактичні заходи слідчого в структурі окремої криміналістичної методики розслідування злочинів / В. А. Журавель // Теорія та практика судової експертизи і криміналістики ; Харків. наук.-дослід. ін-т судових експертиз ім. М. С. Бокаріуса. - Х. : Право, 2013. - Вип. 11 - С. 24-31.

3. Інструкція з організації діяльності органів досудового розслідування Міністерства внутрішніх справ України від 22 жовтня 2012 р. № 1770/22082. Із змінами і доповненнями, внесеними наказами Міністерства внутрішніх справ України від 30 січня 2015 р. № 109, від 30 січня 2015 р. № 110 [Електронний ресурс]. - Режим доступу : http://search.ligazakon.ua /1_doc2.nsf/link1/RE22082.html. 
4. Колесниченко $A$. $H$. $\mathrm{O}$ системе версий и методике их построения / А. Н. Колесниченко, Г. А. Матусовский // Криминалистика и судебная експертиза. - К. : РИОМВД УССР, 1970. - Вып. 7. - С. 7-13

5. Криміналістика : підруч. / В. Ю. Шепітько, В. О. Коновалова, В. А. Журавель [та ін.] ; за ред. В. Ю. Шепітька. - 5-те вид. перероб. і доп. - К. : Ін Юре, 2016. - 640 с.

6. Кримінальний процесуальний кодекс України від 13.04.2012 р. [Електронний pecypc]. - Режим доступу : http://zakon2.rada.gov.ua/ laws/show/4651-17.

7. Настільна книга слідчого: наук.-практ. видання для слідчих і дізнавачів / М. І. Панов, В. Ю. Шепітько, В. О. Коновалова та ін. - 2-ге вид., перероб. і доп. - К. : Вид. Дім «Ін Юре», 2007. - 728 с.

8. Остапчук M. С. Організація та планування провадження досудового розслідування розбоїв, учинених неповнолітніми / М. С. Остапчук // Наук. вісн. Львів. держ. ун-ту внутр. справ. (Серія юридична). - 2014. - Вип. 2. - С. 344-356.

9. Пирожков В. Ф. Криминальная психология / В. Ф. Пирожков. - М. : «Ось-89», 2001. $-704 \mathrm{c}$.

10. Сорока I. B. Особливості проведення слідчого огляду за фактами вчинених неповнолітніми крадіжок майна громадян / I. В. Сорока // Наук. вісн. Дніпропетр. держ. ун-ту внутр. справ. - 2013. - № 4. - С. 444-449.

11. Терещук $О$. Д. Планування розслідування розбійних нападів, вчинених на водіїв автотранспортних засобів / О. Д. Терещук // Форум права. - 2011. - № 1. - С. 1024-1030.

12. Шевчук B. M. Тактична операція як криміналістичний комплекс організаційнотактичної спрямованості / В. М. Шевчук // Наук. вісн. Ужгород. нац. ун-ту. - 2013. - Вип. 23. - Ч. II. - T. 3. -177 c.

Манжос И. А. Планирование расследования краж, совершенных группами несовершеннолетних.

Рассмотрено планирование по уголовным производствах совершения краж группами несовершеннолетних как важнейшая часть досудебного расследования, от которой зависит его качество $и$ эффективность. Разработаны соответствующие рекомендации, определены последовательность следственных (розыскных) действий и версии, которые должны быть включены в структуру плана.

Ключевые слова: кража, планирование расследование преступлений, группа несовершеннолетних, криминалистическая версия. juveniles.

Manzhos I. A. The planning of pre-trial investigation of theft committed by groups of

The article covers the features of planning process of criminal proceedings according to thefts, committed by the group of minors. The author considers the given element of investigative practice as the most important part of the preliminary investigation, on which the quality of the criminal proceedings and its efficiency depends. The author notes that the planning on the initial phase of the proceedings is mostly characterized by informational uncertainty, and exactly the lack of initial data often makes an investigator be satisfied with typical version only in the beginning of this phase.

Key words: theft, planning investigation of crimes, the group of minors, versions.

Надійшла до редколегії 18.12.2015 p. 


\section{Розширена анотація}

\section{статті Манжсс Ірини Олександрівни на тему: «Планування розслідування крадіжок, учинених групами неповнолітніх»}

Manzhos I. A., postgraduate of the Department of criminology, Yaroslav Mudryi National Law University, Kharkiv

An extended abstract of paper on the subject of:

\section{«The planning of pre-trial investigation of theft committed by groups of juveniles»}

Problem setting. The article covers the features of planning process of criminal proceedings according to thefts, committed by the group of minors. The author considers the given element of investigative practice as the most important part of the preliminary investigation, on which the quality of the criminal proceedings and its efficiency depends. The author notes that the planning on the initial phase of the proceedings is mostly characterized by informational uncertainty, and exactly the lack of initial data often makes an investigator be satisfied with typical version only in the beginning of this phase.

Recent research and publications analysis. In this article the author shows the particular recommendations on planning the investigation of thefts, committed by the groups of minors; considers the features of its individual phases; notes that when drawing up the initial plan of investigation, you can't neglect the requirements of the comprehensive and in-depth analysis of the materials, which the inquest is armed with; the detailed elaboration of the versions; on the contrary, it is the detailed development work on provisional plan of investigation that promotes the opportunity of its perfection.

Paper objective. The author as well determines the basic versions, which are included in the structure of the plan; notes that the most perfect investigation plan is supposed to undergo the constant correction taking into consideration new 
Paper main body. The article contains a conclusion that when investigating thefts, committed by a group of minors, the correct organization of planning, welltimed bringing up of versions allows responding to committed crime quickly and making the most efficient use of capabilities, aimed at investigating and detection of crime. All the introduced versions are checked by carrying out the complex of the investigative and operational-research activities. Attempts of individual lawenforcement agencies' employees to investigate these crimes without any plan leads to complications in inquiry work, doesn't allow implementing the system and stageby-stage approach when investigating thefts, committed by the group of minors.

Key words: theft, planning investigation of crimes, the group of minors, versions. 